\title{
没水平板を持つ矩型浮体の動摇特性について DYNAMIC MOVEMENT OF PONTOON TYPE FLOATING STRUCTURE WITH FLAT PLATES
}

\author{
武村 武 1 落合 実 $^{2} \cdot$ 遠藤 茂勝 3 \\ Takeshi TAKEMURA, Minoru OCHIAI and Shigekatsu ENDO \\ 1学生会員 工修 日本大学大学院生産工学研究科（テ275-8575 習志野市泉町1-2-1） \\ 2正会員 工修 日本大学講師 生産工学部土木工学科（テ275-8575 習志野市泉町1-2-1） \\ ${ }^{3}$ フェロー会員 工博 日本大学教授 生産工学部土木工学科（テ275-8575 習志野市泉町1-2-1）
}

\begin{abstract}
Pontoon type floating structure with submerged flat plate has been studied in this paper. Wave response analyses of the pontoons have been performed for several different attached positions of flat plate and the stability of the pontoons were examined. Furthermore, the characteristics of the hydrodynamics such as the reflection and a transmission ratio were examined.

It was verified that the flat plate have worked effectively for mitigation of the heaving motion, especially it is obvious to the plate area of 2 times of surfaces area at the water line and 0.02 or more wave steepness. It was confirmed that the dimension and attaching depth of flat plates important factor for motion control of a floating pontoon. The possibility of the stable improvement and the effective wave control by the size and position of the flat plate were shown.
\end{abstract}

Key Words : Floating structure, motion control, hydrodynamics force

\section{1.はじめに}

沿岸海域において高度な多目的利用を実現するに は静穏な海域の確保と, その海域の利用手段を確保 する必要がある. 今, 広い海域を考えたとき両者の 目的にかなう構造物として浮体式構造物があげられ る.

浮体式構造物は, 海洋空間利用という面で水深や 海底の性状などの制約を受けないばかりか, 浮力を 利用した大型構造を考えたとき，広いスペースを有 効に利用できることや, 移動が可能であることを考 えあわせると利用価值の高い構造物といえる. しか し, 波の作用に伴う動摇が著しく利用上の課題が残 されている.

本来, 浮体の動摇を軽減することは容易ではなく, 浮防波堤や栈橋などではある程度の動摇を許容して きた. また，浮防波堤では浮体の運動に伴うスラミ ング現象や運動の位相差などを利用する例むあり, 浮体の動摇を積極的に軽減しようとする試みは少な かったように思われる.一般に浮防波堤などにおい て波浪の制御効果が期待されるのは, 浮体幅の4〜5
倍程度の波長の波までが限度であるといわれるよう に, 比較的周期の短い波に有効で, 長周期の波では 動摇が大きいことを示している.

そこで，ここでは海洋空間利用を発展させる意味 を含め, 波浪制御効果に異なった周波数帯を持つ構 造形式を組み合わせたハイブリット型ともいうべき 没水平板付浮体の検討を行った. 没水平板による波 の制御に関する研究としては入江ら ${ }^{1) 2}$ ()研究があり, 波の制御に有効であることが明らかにされている. また, 浮体と組み合わせた研究としては小島ら ${ }^{3), 4)}$, 増田ら ${ }^{5)}$, そして著者ら ${ }^{7)}$ の研究があるが理論值と実 験値の整合性は必ずしも良くない.

そこで, 消波性能として浮体が短周期の波の制御, そして没水平板が長周期の波の制御に有効であるこ とから, 浮体形状や係留の有無によってどの程度の 波長の波にまで安定性の確保が可能であるか, また その時の没水平板の必要面積や取り付け深さなどに よって浮体の挙動がどのように変化するかを調べる 研究の一環として，ここでは浮体の主要な運動であ る heavingに主眼をおいて, 浮体幅をパラメーター とした害験を行い動摇特性について検討した. 


\section{2.実験装置および実験浮体}

\section{（1）実験・計測装置および実験条件}

実験に使用した造波水槽は長さ $27.6 \mathrm{~m}$, 幅 $0.7 \mathrm{~m}$, 高さ $1.0 \mathrm{~m}$ の両面ガラス張りの鋼製 2 次元水槽で，一 端にピストン式造波装置が取り付けられている。水 槽の両端にはスリット式の低反射消波装置がおかれ ている.

実験条件としては，ここではやや長周期の波に対 する浮体の安定性についての検討を考えているため 入射波形勾配が 0.02 程度の波についても対象とした. 実験条件は表一 1 に示した通りである。ここで入射 波高（Hi） は浮体を設置する前に造波機から $13.0 \mathrm{~m}$ 地点で予め測定した波高である.

実験に使用した浮体モデルは, 浮体の下部水中部 分にシャフトで水平板を固定した没水平板付矩型浮 体である。

また実験では，カラービデオ画像を用いて動摇解 析を行うために3色の発泡スチロール製カラーボー ルを浮体の前後と重心線上の位置に設け，水槽側面 より2台のCCDカメラによって撮影した，収録され た画像は動摇解析装置本体に1/60秒每に取り込まれ, デジタル化されたカラーボールの重心位置を, 静止 状態からの移動量として表示される.

そして, 浮体の動摇とは別に, 浮体前後の波の計 測を行うために, 図ー1に示したように沖側では入 射波測定用に1台, 反射波測定用に2台, 岸側では透 過波測定用に3台の計6台の容量式波高型を設けた。

また，係留については極力自由度を妨げない状態 で浮体の動摇を比較する観点から全く係留せずフ リーの状態と，入射側に2点係留を施した2通りにつ いて実験を行った。

\section{(2) 浮体モデル}

実験では18種類の浮体について動摇の計測をした がここでは表ー 2 に示すように基本浮体として浮体 幅 $\mathrm{B}=30.0 \mathrm{~cm}$ に対して2倍の $\mathrm{B}=60.0 \mathrm{~cm}$ ，そして 4 倍の 幅を持つ $B=120.0 \mathrm{~cm}$ の種類を用いた。 それぞれの 浮体において, 下部水中部に浮体の吃水面よりやや 大きめでフィン付のアクリル製水平板が1枚または2 枚取り付けられている，水平板に取り付けられてい るフィンは高さ $5.0 \mathrm{~cm}$ で浮体の水平移動を抑制する ために設けてある. 実験に使用した浮体モデルの詳 細図の一例を示したものが図ー2である.

ここに示した浮体はM-1型浮体モデルで水平板の 取り付け深さは浮体下部より $9.0 \mathrm{~cm}$ 間隔としている がその位置が最も梁いプレートポジション（PL. No.5）の位置にのみ取り付けたもので，浮体サイズ はB=30.0cm である. 同様に, $\mathrm{B}=60.0 \mathrm{~cm}$ の浮体を $\mathrm{S}$ 型浮体とし，S-3型浮体とはプレートポジションが No.3 とNo.5の位置に同一種類の水平板が2枚ついて いる浮体である. また $\mathrm{B}=120.0 \mathrm{~cm}$ 浮体はL型浮体 である．実験においてM型浮体のみ係留されている.

\section{表- 1 実験条件}

\begin{tabular}{|c|c|c|c|c|}
\hline $\begin{array}{c}\mathrm{h}-\mathrm{T} \\
(\mathrm{cm})(\mathrm{sec})\end{array}$ & $\begin{array}{c}\mathrm{Hi} \\
(\mathrm{cm})\end{array}$ & $\begin{array}{c}\mathrm{L} \\
(\mathrm{cm})\end{array}$ & $\mathrm{Hi} / \mathrm{L}$ & $\mathrm{h} / \mathrm{L}$ \\
\hline $70-1.0$ & 6.79 & 154.91 & 0.044 & 0.452 \\
\hline $70-1.2$ & 6.05 & 216.94 & 0.028 & 0.323 \\
\hline $70-1.4$ & 4.94 & 280.30 & 0.018 & 0.250 \\
\hline $70-1.6$ & 3.75 & 342.45 & 0.011 & 0.204 \\
\hline $70-2.0$ & 2.98 & 462.07 & 0.006 & 0.151 \\
\hline
\end{tabular}
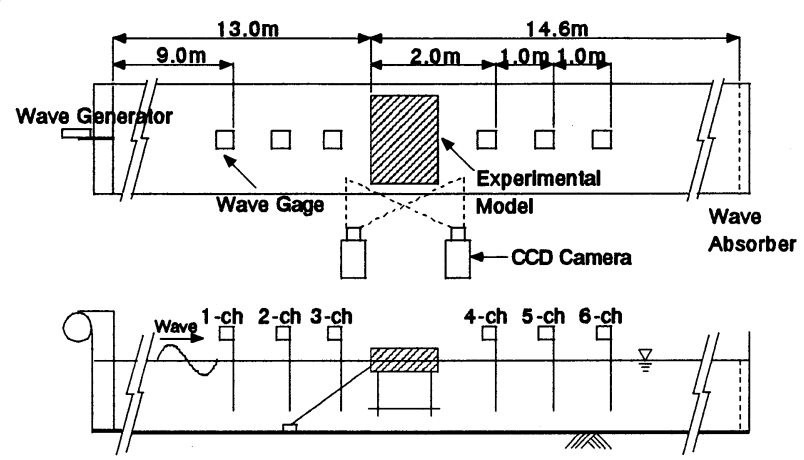

図ー 1 実験水槽および波高計配置図

表ー2 浮体モテル一覧表

\begin{tabular}{|c|c|c|c|c|}
\hline Model & Pontoon Size $(\mathrm{cm})$ & Plate Position & Draft(cm) & Plate Size $(\mathrm{cm})$ \\
\hline L.0 & \multirow{3}{*}{$30 \times 120 \times 11$} & none & 3.2 & none \\
\hline L-2 & & No.5 & 3.4 & $45 \times 140$ \\
\hline L-3 & & No.3, No.5 & 3.4 & $45 \times 140 \times 2$ \\
\hline S.0 & \multirow{3}{*}{$30 \times 60 \times 11$} & none & 3.0 & none \\
\hline S-2 & & No.5 & 3.3 & $45 \times 80$ \\
\hline S-3 & & No.3, No.5 & 3.3 & $45 \times 80 \times 2$ \\
\hline$M=0$ & \multirow{5}{*}{$60 \times 30 \times 11$} & none & 3.3 & none \\
\hline$M-1$ & & No.5(S) & 3.3 & $45 \times 60$ \\
\hline$M-2$ & & No.5(L) & 3.5 & $60 \times 60$ \\
\hline$M-3$ & & No.3, No.5(S) & 3.9 & $45 \times 60 \times 2$ \\
\hline$M-4$ & & No.3, No.5(L) & 3.9 & $60 \times 60 \times 2$ \\
\hline
\end{tabular}

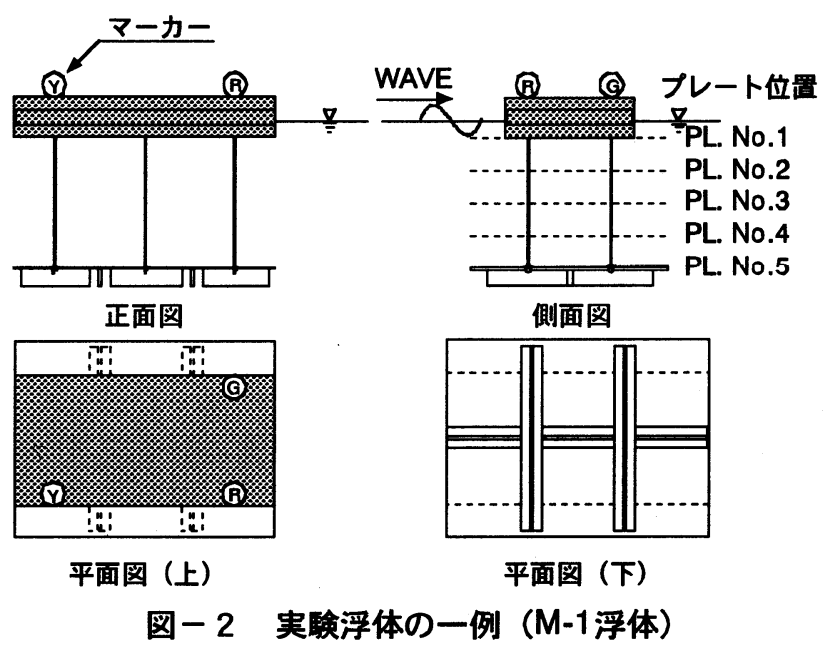




\section{3.実験結果と考察}

\section{（1）基本浮体の動摇特性}

本実験では, 浮体幅の異なる3つの浮体を基本浮 体として用いているが水平板の取り付けられていな い浮体についてのheaving特性の実験結果を示した ものが図ー 3 である。横軸には波長（L) に対する 浮体幅（B）の比を取り, 縦軸にはheavingの振幅 （ $\eta$ ）を入射波高（Hi）で無次元化したheaving量 （ $n / \mathrm{Hi} ）$ をとって示したものである. M型浮体に 対してS型浮体は2倍, L型浮体は4倍の浮体幅を有し ているがL/B=6.0以下の波，すなわち浮体幅の6倍以 下の波長の波では波長が短くなるほど heaving 量が 減少するが，逆にそれより長い波長を有する波に対 しては浮体は波の振幅に等しいheavingとなってい る.この事より，一般にいわれるポンツーン型浮体 の消波効率の限界（L/B $\fallingdotseq 5.0 ）$ と本実験における結 果はほぼ一致していると考えられる。

\section{（2）板付浮体の動摇特性}

次に浮体の水面下に水平板を取り付けた浮体の heaving特性の実験結果についてまとめたものが図 - 4 である. この図も横軸に相対浮体幅（L/B）を 取り, 縦軸に $\eta / \mathrm{Hi} と っ て$ 示したものである.

この結果では，浮体幅が異なるので同一の波に対 しても横軸の位置はややずれたところに表示されて いるが浮体に対する水平板面積の割合がほぼ等しい L-2，S-2，M-1型浮体では，heaving特性はほぼ同様 の傾向を持っていることが示されている．特に， M-1型浮体では沖側が係留されているがその影響は あまり見受けられない。しかし，M-2型浮体ではM1型浮体と同じ1枚板であるが水平板の面積が約 $30 \%$ 程度増加されており, その事によってheaving量が 著しく減少し, 相対浮体幅 $\mathrm{L} / \mathrm{B}=16.0$ 程度においても， heaving量は入射波高值の約60\%程度まで軽減させら れることが認められる。これは没水平板のエッジが 入射波の作用を受ける浮体の入射面より沖㑡に引き 出されているため, 波が入射して浮力を受けて浮体 の入射側が上昇しょらとして浮体の重心，㫣たは岸 側端部を中心とした回転モーメントが働くときに， 水平板を囲んで存在する流体の粘性抵抗力がM-2型 浮体の方が水平板の張出部が多い分抵抗力が増加し heavingの軽減に寄与しているものと考えられる.

\section{（3）係留浮体の動摇特性}

M-1型浮体とM-2型浮体では没水平板の面積がや や増加するだけでheavingが著しく減少するので, 係留浮体における没水平板の効果について検討を 行った.

係留浮体M-0，M-1，M-2，M-3型浮体の4浮体に おける heaving特性の実験結果をまとめたものが図 - 5 である.

M-0型浮体は没水平板を有しないので相対浮体幅

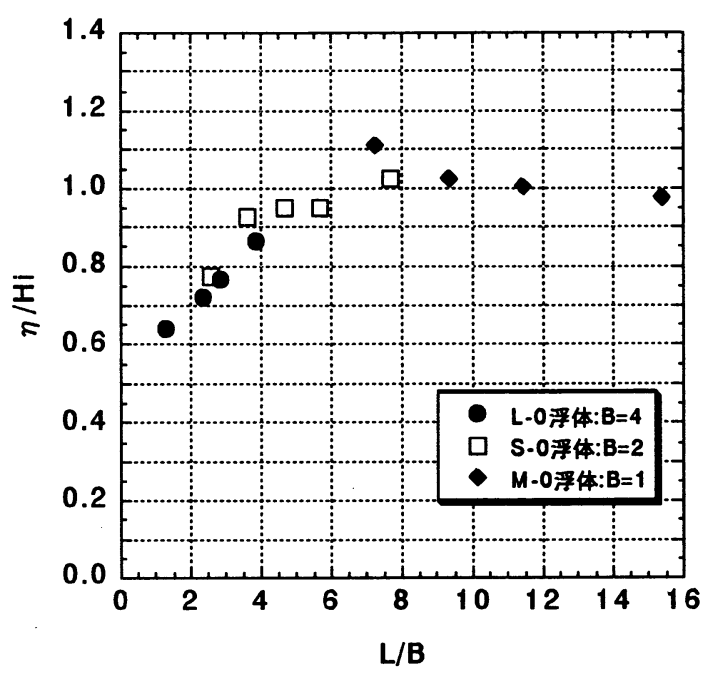

図一 3 基本浮体のHeaving特性

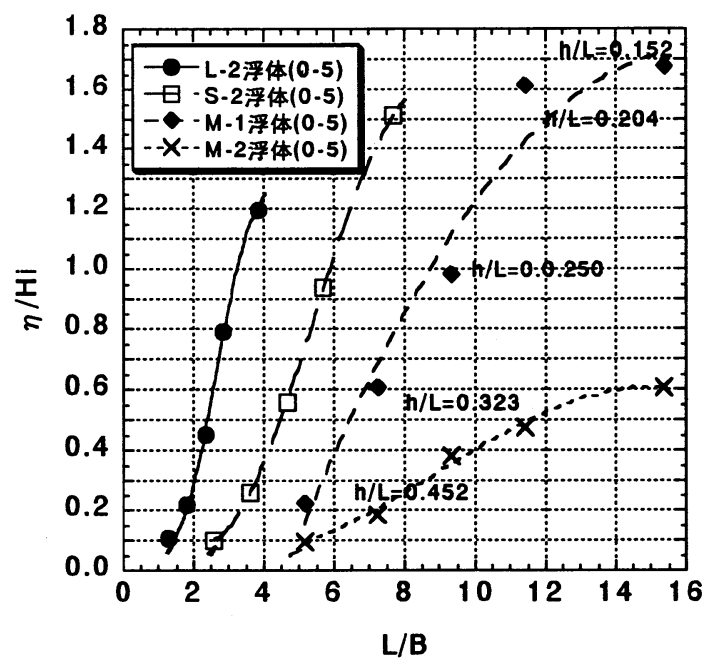

図ー4 1枚板を有する浮体のHeaving特性

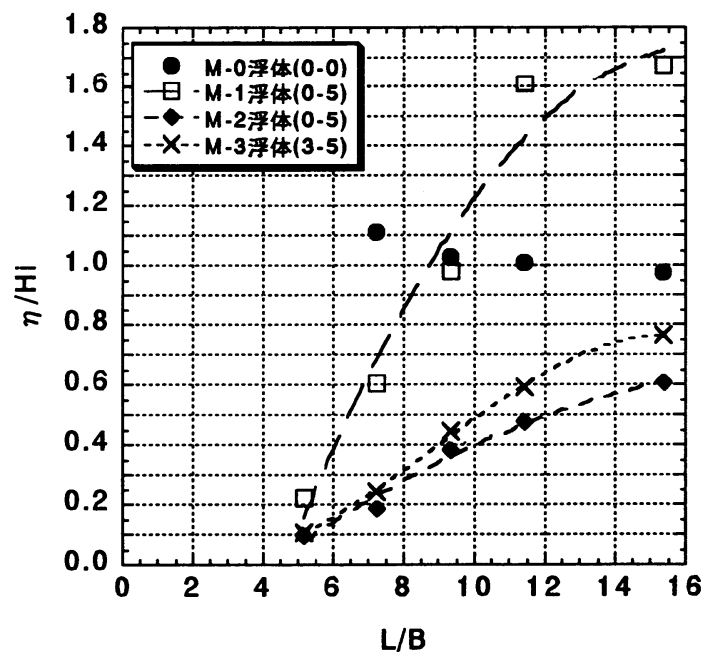

图一 5 係留浮体のHeaving特性 
に対する heavingの結果は, ほぼ一定值を取り入射 波と同様な振幅で運動していることが示されている.

一方，没水平板を1枚有するM-2型浮体と2枚有す るM-3型浮体では，M-3型浮体の方が没水平板の面 積比では約50\%む多いのにもかかわらずheavingの結 果に著しい差が認められず, 取り付け面積比の大き い浮体の方がheavingが若干大きくなっている。 こ れは, 没水平板の取り付け位置に関係があると考え られる.M-3型浮体では没水平板2枚のうち1枚が水 深の浅い部分に設置されているため, 波の入射時に 波の作用を受けて浮体を振動させるのではないかと 考えられる.このことより，没水平板の取り付け位 置によってはマイナスの効果となることを示してい ると思われる。

しかし，M型浮体では没水平板を設けることによ り $\mathrm{L} / \mathrm{B}=16$ 程度の浮体幅に対して波長の長い波でも heavingを $60 \%$ 以下に抑制することができ，没水平板 がheavingの軽減に効果的であることが示されてい る.

\section{（4）浮体規模によるheaving特性}

基本浮体に没水平板を2枚としたときのheaving特 性に実験結果を示したものが図ー6である．図の結 果で示されるように没水平板を2枚とした場合では $\mathrm{L} / \mathrm{B}=4.0 \sim 8.0$ 程度の範囲において浮体幅の効果は少 なく，波に対する heavingの軽減にはあまり効果的 でないようである．また，M型浮体は係留してある のでその効果も見逃せない点と考えているが浮体幅 の狭い方が波が透過しやすいことから heavingが少 ないとも考えられるので伝達波等の検討もする必要 がある.

\section{(5) 係留浮体の反射率と伝達率}

浮体が海域に設置された場合の周辺の海域への影 響として配慮しなければならない点として浮体から の反射波と伝達波の問題がある。そこで浮体の heaving との関連で反射率, 伝達率について検討し た. 反射波高はHealyの方法で求め，伝達波は浮体 背後1.0mに設けた浮体にもっとも近い地点の測定結 果を用いて各浮体ごとにまとめたものが図ー 7 であ る.

M-1型浮体とM-2型浮体は図ー4，5 で示したよ 亏に，同じ1枚板の場合であるが板の面積がやや異 なるもののheavingの傾向が著しく異なるので，そ れらの浮体についての反射率，伝達率を示した．図 に示されるように反射率では $\mathrm{L} / \mathrm{B}=5.0$ に対して $\mathrm{Kr}=0.3$, そして $\mathrm{L} / \mathrm{B}=15$ に対して $\mathrm{Kr}=0.05$ 程度で, 両者はほとんど差が認められないのに対して, 伝達 率ではL/Bの小さいところで10\%程度の差違が認め られる. 従って反射率と透過率を見る限り両者の運 動の差による違いは認められない。 また，M-2型浮 体とM-3型浮体では没水平板が1枚と2枚であるが heaving量の差は少なくほぼ同一の傾向を持ってい ることもあり, 反射率, 伝達率ともほとんど一致し

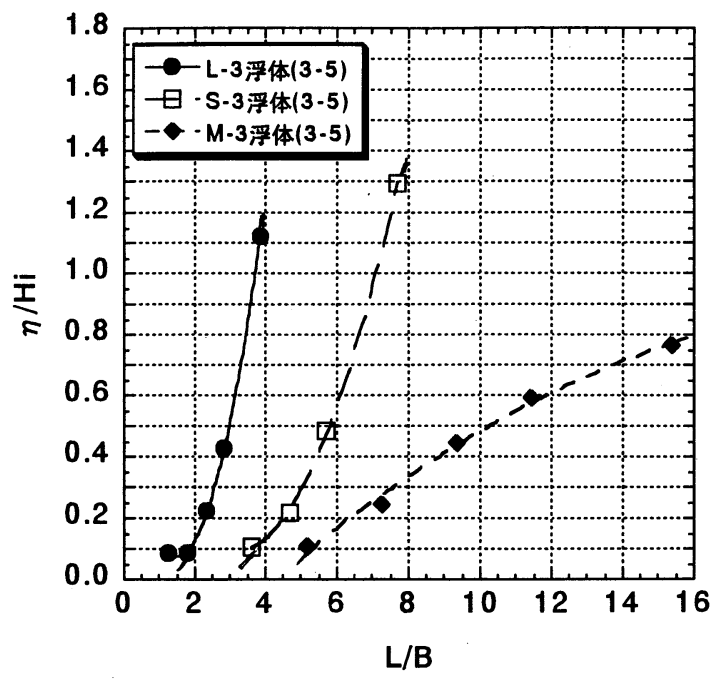

图－6 浮体規模によるHeaving特性

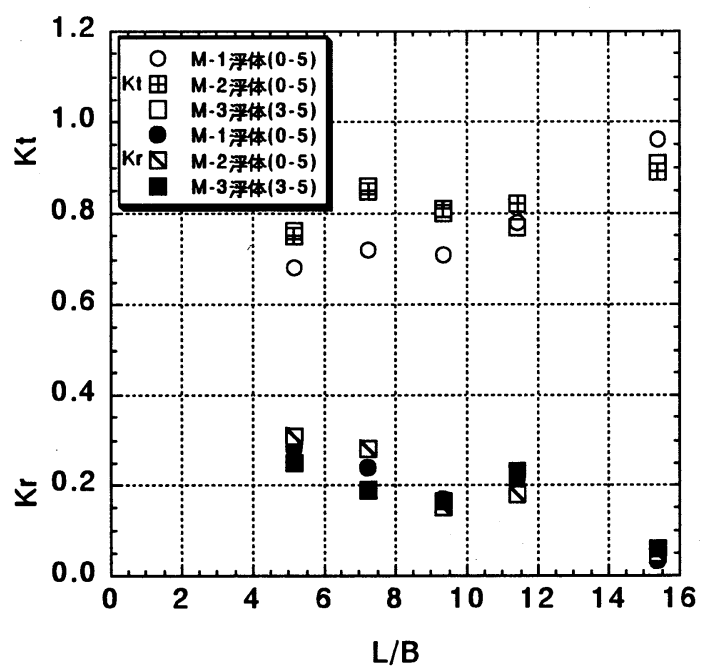

図-7 透過率・反射率

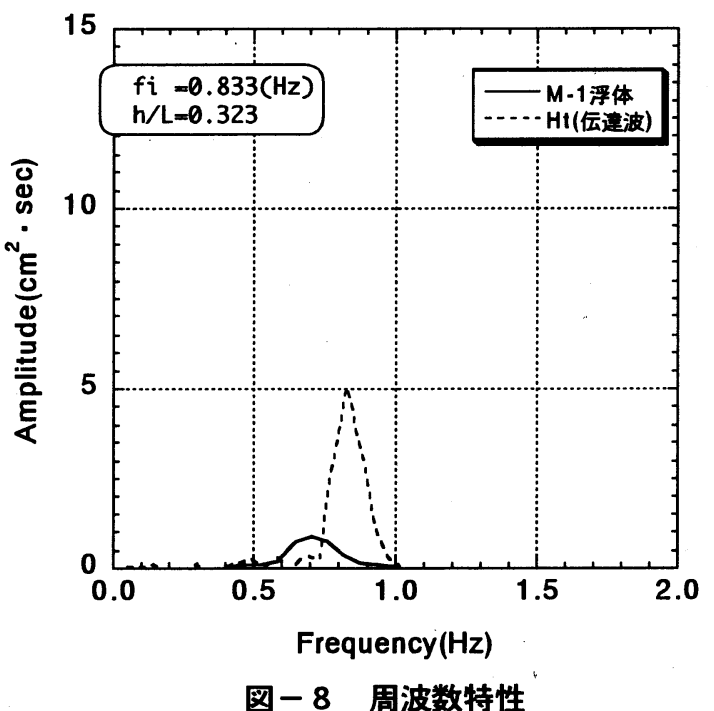

図-8 周波数特性 


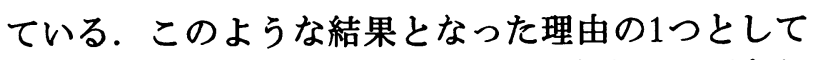
考えられることはいずれの浮体の場合む吃水がきわ めて浅く，入射波が通過しやすい浮体であることが あげられる。

\section{（6）浮体と伝達波の周波数特性}

この実験では規則波を対象としているが，没水平 板付の浮体からの反射波や伝達波には, 入射波の周 波数とは異なった周波数帯の波が発生することが報 告されているのでそれらの検証を行った。 また，そ のような結果が認められる場合には浮体自身が入射 波特性とは異なった運動が卓越するむのと考えられ る. そこで，浮体の運動と伝達波の時系列記録から 周波数解析を行った. その結果の一例を示したもの が図ー8，9である。

図一 8 はM-1型浮体における結果である.この結 果によれば, 浮体の卓越周波数は入射波の周波数 $\mathrm{fi}=0.833(\mathrm{~Hz})$ よりやや小さな值となり分布も広くな り浮体の運動周期が長くなっているのに対して, 伝 達波の卓越周波数はほぼ入射波のそれに等しいが周 波数帯の幅がかなり広がっていて入射波の周期より かなり異なった周期の波が伝達されていて, その上 振幅もかなり減衰していることが認められる.この ことから，M-1浮体では浮体の運動周波数が短くな り，その結果heavingが卓越するものと考えられる.

また, 図一 9 に示したM-2型浮体も同様に入射波 周波数 $\mathrm{fi}=0.833(\mathrm{~Hz})$ の場合の浮体の運動と伝達波の 周波数特性である. 浮体の運動周波数帯がきわめて 広くなっている. 一方伝達波の方にも入射波より長 周期や短周期の波が認められるが，入射波周期と同 じ周期の波が卓越していることがわかる.このこと より，M-2型浮体では没水平板の効果として入射波 周期と異なった複雑な周期の運動を含んでいるため heavingが軽減されたものと推察される.また，逆 にheavingが少ない分, 没水平板による流体の擋乱 や渦の発生が少なく伝達波が大きくなるものと推察 される.

\section{（7）浮体のheaving とpit ching特性}

これまで主として浮体のheavingについて述べて きたが浮体の運動のheavingに対する浮体のpitching 角の関係を併せて示したのが図ー 10 である.この 結果は, 縦軸には静水面を基準とした浮体の変位量

（士n/Hi）を取り, 横軸に浮体の静水面に対する 傾斜角 (deg) をとったものである. この図は没水 平板の取り付けられていないS-0型浮体と2枚取り付 けられているS-3型浮体の結果を重ねたものである. 波の条件は入射波波形勾配 $\mathrm{Hi} / \mathrm{L}=0.039$ と比較的波高 が大きいが, 相対水深 $\mathrm{h} / \mathrm{L}=0.323$, 相対幅 $\mathrm{L} / \mathrm{B}=3.6$ と 比較的波長の短い波の場合の結果である.S-0浮体 では, 入射波とほぼ同様の振幅と傾斜を持っている ことがわかるが，S-3型浮体ではheaving, pitchingと もに少ないことがわかる. このように没水平板付浮 体では浮体の動摇や傾斜を著しく軽減することがで

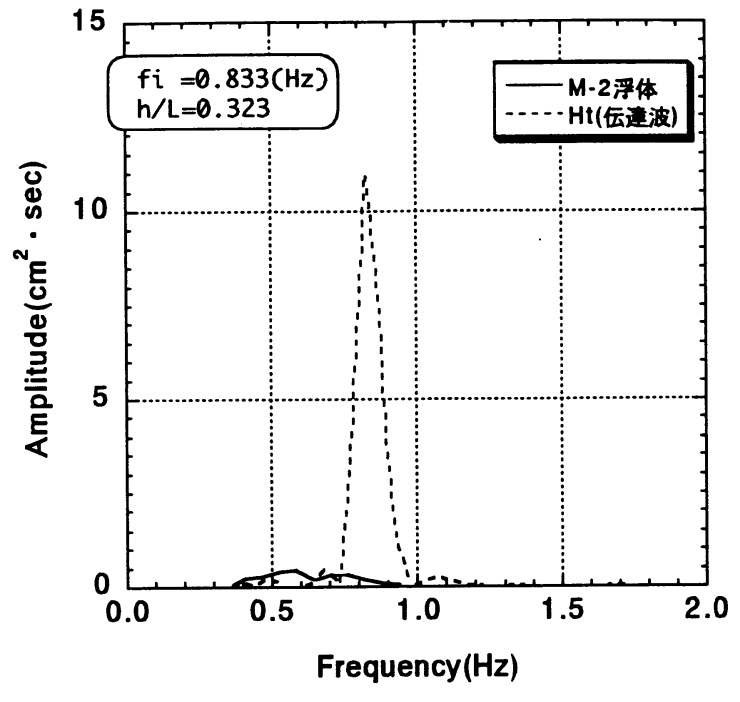

図-9 周波数特性

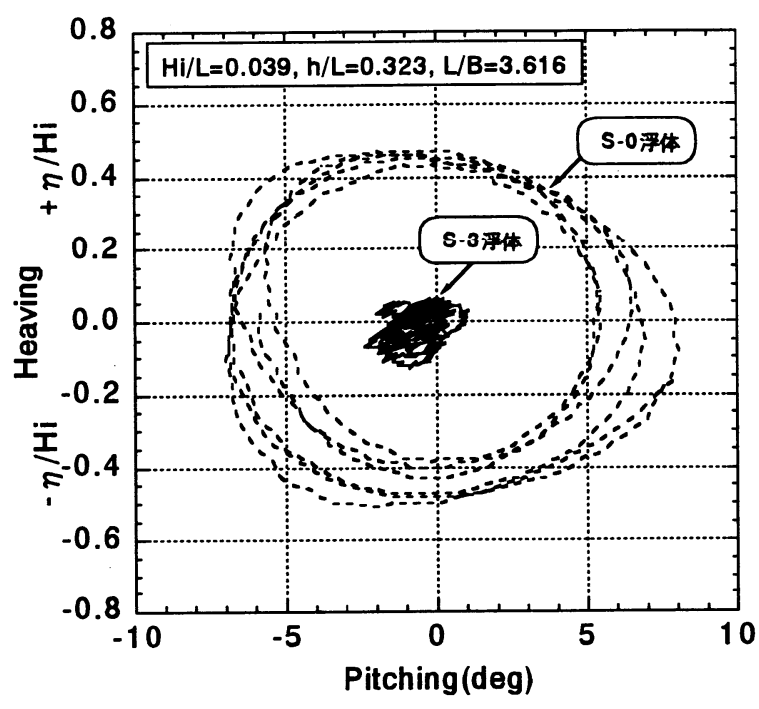

図ー 10 PitchingとHeavingの相関

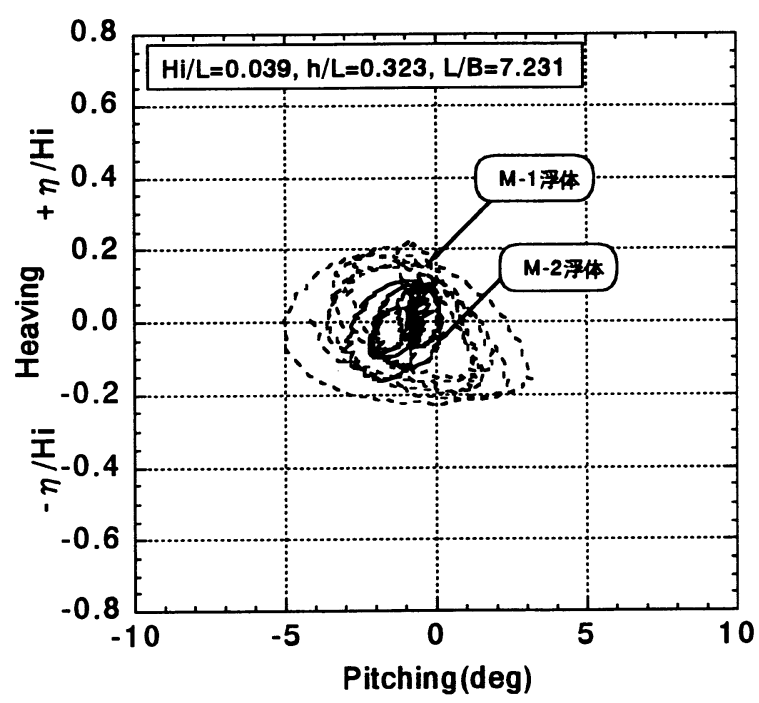

図-11 PitchingとHeavingの相関 
きるので浮体の安定性の確保の方法として有効と考 えられる。

また，図一 11 は係留された浮体のうち，比較的 安定性の悪いM-1型浮体と安定性の良いM-2型浮体 を同様な軸で示したものである．相対幅はL/B=7.23 と比較的大きな条件である. M-1浮体ではM-2浮体 と比較して heavingが大きいだけでなく pitching も著 しく大きくなり, 浮体の動摇は極めて複雑な運動を していることがわかる.

M-2型浮体では，L/Bが大きいにも関わらずS-3型 浮体に近い運動であることが確認される.

\section{4.まとめ}

本研究の結果, 没水平板付矩型浮体の動摇特性を 明らかにすることができ, 要約すると以下のように まとめられる.

（1）没水平板が1枚の場合では，浮体の吃水面にお ける面積と取り付け没水平板の比率が同一の浮体 の場合では，入射波の波形勾配が 0.03 以上でL/B が10以下では浮体幅が大きくなっても heaving特 性は基本的には変化せず, heavingに対する抑制 効果は同程度であることが明らかとなった. また, 係留浮体においても heavingの傾向はほぼ同様の 傾向を示し, 係留による影響は少ないようである.

（2）没水平板が1枚の場合でも，その面積を増大さ せたM-2型浮体では当然の事ながら heavingの抑制 効果は大きくL/Bが16程度でも $\eta / \mathrm{Hi}$ が0.6程度であ ることから没水平板の効果が著しいことがわかる.

（3）同じ係留浮体の場合でも, 没水平板の取り付け 面積によって動摇特性は著しく変化し, 没水平板 の面積が少ないとあまり効果がないが，没水平板 2枚を離して取り付けたものと1枚をやや大きくし たものとでは, 1枚の方がheavingの抑制効果は大 きく必ずしも2枚とする必要はない．このことは, 比較的浅い部分に取り付けることにより板が入射 波による作用を受けて安定性が悪くなるものと考 えられる。

（4）ポンツーン型浮体に没水平板を2枚取り付けた 場合, 浮体幅の長い場合と短い場合では浮体幅は 長い方がheavingに対して安定性があり，L/Bの広 い範囲に対して安定度が確保される.

（5）没水平板付浮体のうち平板の面積が浮体の吃水 面にほぼ等しいようなときは浮体の運動周期が長 くなり没水平板を取り付けたことにより長周期の 運動をさせる結果となり heavingがあまり抑制さ
れない. しかし，この場合でも伝達波には効果が あり伝達波の周波数帯を広げ, 振幅の低減に効果 を有している.

（6）没水平板の面積が十分でheavingの抑制効果が著 しいM-2型浮体では幅広い周波数帯の運動となる が，伝達波は入射波の周波数特性が強くあまり低 減していない。

(7) 浮体の運動はheavingのみならずpitching等も考 慮する必要がある。一般に没水平板付浮体では heavingを低減させることができるだけでなく pitchingをも著しく軽減できることが明らかと なった.

以上, 没水平板を持つ矩型浮体の動摇特性につい て検討してきたが，浮体の規模, 没水平板の取り付 け位置と必要面積を考慮すればheavingのみならず pitchingをも軽減できるので, 浮体の安定性の確保 に役立つと思われる.

なお, この研究は「平成6年度研究所大型機器設 備（動態情報解析機器装置）」を用いた研究である ことを付記する。

\section{参考文献}

1)入江功, 信岡尚道, 小島治幸, 三原泰司 : 底版型 潜堤の波浪減殺効果, 海岸工学論文集, 第 38 巻, pp561 565, 1991.

2)入江功, 小島治幸, 古賀䉷 : 浮体と没水平板の八 イブリッド構造物による波の制御, 海岸工学論文 集, 第40巻, pp631〜635, 1993.

3)小島治幸, 入江功, 池崎靖: 浮体と没水平板によ るハイブリッド消波堤の水理特性に関する研究, 海岸工学論文集, 第41巻, pp751〜 755, 1994.

4)小島治幸, 入江功, 関本恒浩 : 鉛直運動を許容し たハイブリッド消波堤の水理特性, 海岸工学論文 集, 第45卷, pp711 715, 1998.

5)増田光一, 高岩千人, 八木英紀 : 没水平板を用い た浮栈橋の動摇軽減に関する研究, 海岸工学論文 集, 第42巻, pp981 985, 1995.

6) 中村孝幸, 加藤健一, 河野徹, 上村稳 : スラミン グ現象を利用した浮防波堤の波浪制御効果につい て, 海洋開発論文集, Vol.14, pp311 316， 1998.

7)落合実, 遠藤茂勝 : 水平板によるポンツーンの動 摇制御に関する基礎実験, 海洋開発論文集, Vol.11, pp345 350, 1995. 